\title{
Fatto in Italia: Refashioning Italy
}

\author{
Tiziana Ferrero-Regis, Queensland University of Technology
}

The emergence of the 'Made in Italy' brand in the early 1980s had two functions. First, it helped industrial reorganisation based on technological restructuring, flexible specialisation and high-quality manufacturing for export, and second, it redefined a shattered national identity away from political engagement towards rampant consumerism. By the end of the 1980s, Italy had become the fifth largest industrial economy in the world. This startling recovery-a 'second economic miracle' as Ginsborg (1990: 409) defined it—could not have taken effect without a significant domestic increase in mass consumption and the relative political stability of Bettino Craxi’s centre-left government.

In fact, the Craxi government was fundamental in putting 'Made in Italy' at centre stage, substituting cinema with fashion and design both as cultural industry and as points of reference for artistic research. This article explores the ways in which the rise of Italian fashion design in the 1980s, through the successful branding and marketing of 'Made in Italy,' was central to the economic and cultural rebranding of Italy within the country itself. In particular, I am interested in understanding contextual historical and cultural elements, as well as changes in industrial practices, which were fundamental in determining the success of Italian prêt-à-porter design from the 1980s onwards. The international success of 'Made in Italy' has already been surveyed (see White 2000, especially in relation to the opening of the US market), but a cultural reflection about the historical elements that determined the wide acceptance of fashion nationally has yet to be written. It is not possible to understand the 1980s success of 'Made in Italy' in its 
own country without taking Italy’s rampant consumerism and profound historical changes into consideration.

Elizabeth Wilson (1985) argues that fashion and the city are interdependent because urban spaces offer a backdrop for the performance of clothes. A vitality and quality of life are essential for fashion if it is to grow in the place where purchases are made (Segre Reinach 2006: 133). Thus the expansion of the 'Made in Italy' brand in the 1980s must be seen in relation to the rise of Milan as the Italian capital of ready-to-wear fashion. In that period, due to the growth of Berlusconi’s commercial television networks, Milan became a media city. During the 1950s and 1960s, within a geographical division of the cultural industry that saw Rome and Cinecittà growing as the national and international epicentre of cinema production, ${ }^{1}$ Milan secured its role as an advertising capital. Well before it became the capital of fashion Milan was also the capital of design, publishing and journalism, and this in turn provided the infrastructure necessary for the development of the ready-to-wear industry (Segre Reinach 2006: 125). Taking the above into account, this article offers an interlinked analysis of the Italian cultural, political and economic contexts of the 1980s and the fundamental role of designers in determining the success of 'Made in Italy' nationally and internationally.

\section{Political background}

In the mid-1970s the centre of Italian fashion shifted from Florence and Rome to Milan, which became the major staging ground for Italian ready-to-wear collections and simultaneously for haute-couture. Milan was Bettino Craxi's hometown, and with the first government headed by the socialist secretary in 1983, the city’s economic power became closely connected with political power through a patronage-style relationship. This relationship would later cause a number of scandals connected to corruption and bribery, which culminated with the Tangentopoli inquiry in 1991. The inquiry targeted two-thirds of the Italian Parliament and eventually led to the collapse of the traditional party system. $^{2}$

\footnotetext{
${ }^{1}$ However, this was short lived, as a structural and financial crisis hit Cinecittà studios in 1970. Cinecittà had serviced much US offshore film production since the early 1950s. This in turn created opportunities for local filmmaking to the point that in the early and mid-1960s, Italian films dominated the national box office. After the withdrawal of Hollywood in 1970, the Italian cinema industry suffered the longest crisis in its history.

${ }^{2}$ For a comprehensive analysis of events pre- and post-Tangentopoli, see: Diamanti and Lazar 1997; and Sassoon 1995.
} 
Between 1979 and 1983 Italy was hit by recession. A series of political crises produced six governments in four years, headed by different prime ministers who led party coalitions with very little variations (Santarelli 1996: 257). The 1983 elections penalised the Christian Democratic Party, while the Socialist Party offered an alternative to the Communist Party by moving its policy and reforms to the centre. The Craxi government lasted for four years between 1983 and 1987. The period coincided with the financial boom of 1985-86, which touched all aspects and structures of life. National pride and unity had also partially been restored with Italy's victory in the Soccer World Cup in the Summer of 1982, with a memorable final match between Italy and Germany, which recalled the 1970 match between the two nations. The 1982 game was watched by most Italians, no matter what their political colour. Andrea Barzini’s film, Italia-Germania 4 a 3 (1990), well summarises the disillusion and bewilderment of the generation of 1968 in the face of the disintegration of love relationships and political commitment, with the replaying of the soccer match in the background.

To understand the radical shift of 1980s politics, we have to look back in time. The crisis of collective political movements that dominated much of Italian social life in the 1970s created a cultural and political environment ripe for change in the early 1980s. The culture of individualism and hedonism, an effect of the riflusso (flowing back), extended to all sectors of public and private life, and supported the birth and growth of brands as a commodity fetish. ${ }^{3}$ In 1987, Laura Laurenzi wrote:

\begin{abstract}
Yes, Italy is becoming a country of rich people in which the dedication to luxury is an end that is spreading more and more and that is capricious ... Until recently, we were ashamed to be rich, now Italy is pervaded by a febrile desire of capitalism. A nice wish, a hot desire for entrepreneurship and profit. The ethics of dignified poverty has been swept away, it has drowned in the mourning grey of the 1970s. Now money, according to paradigms that once belonged only to protestant cultures, is a divine grace: those who are rich are elected by God. (Laura Laurenzi, quoted in Cappellieri 2007: 41)
\end{abstract}

In fact, from the early 1980s, industrial restructuring connected to processes of global financing of advanced capitalist countries converged with the emergence of new entrepreneurial and financial groups, and the reduction of industrial proletarians, with

\footnotetext{
${ }^{3}$ In 1980, the weekly Panorama published an article with the title "Si fa presto a dir riflusso" (7 January) which officially sanctioned the term riflusso as the indication of the dislocation between society and politics, with the consequent abandonment of collective action and goals by the movements of the 1970s. The era of riflusso signalled a return home, which in turn was represented in domestic films by an aesthetic of enclosed spaces and claustrophobia. See Ginsborg (1990: 401) on the topic of the demise of the protest movements between 1976 and 1979.
} 
the subsequent growth of the middle class and the service sector. Neo-conservative tendencies in Europe and the USA aggravated the crisis of ideologies, ${ }^{4}$ while the increasing influence of mass media on a society that was becoming progressively more individualist and self-centred presented new generations with a system of values based on profit and success, as Laurenzi's comments above well summarise.

Here it is worth recalling an important political event that took place at the end of the 1970s. After the youth movements of 1968 and the ensuing decade of terrorism, practised by both extreme Left and Right groups, which culminated in 1978 in the kidnapping and murder by the Red Brigade of Aldo Moro, the secretary of the Christian Democratic Party, Italy suffered a crisis of national identity and representation. In response to the killing of Moro, the Italian government approved emergency legislation to defeat terrorism. It is generally recognised that the death of Moro marked the crisis of Italian red terrorism, but it also raised important questions about the relationship between citizens and the state that had been left unanswered for many years. The Moro affair thus provoked a profound crisis of identity and representation in the Italian nation that went well beyond political contingencies.

Emergency legislation was tested on 7 April 1979, when 71 people-including Antonio Negri, a professor of political theory at the University of Padua and a leading figure in the Autonomia Operaia (Workers’ Autonomy) movement-were arrested and charged with being the leaders of the Red Brigades, operating through the legal front of Autonomia Operaia. These charges were later quietly dropped when a leader of the Red Brigades, Patrizio Peci, collaborating with the prosecution, testified that Negri and the other people arrested had nothing to do with the murder of Moro. Nevertheless, the leaders of Autonomia Operaia were charged with promoting an insurrection and organising an armed band. The attack against Autonomia was crucial to the end of the radical Left, and, by large, of post-1968 radical movements. The arrests opened a period of political conformism that accelerated the wider process of historical revisionism. From the experiences of collective politics and student and worker movements, a sense of loss and disorientation pervaded the generation of 1968 in the 1980s. Thus the events

\footnotetext{
${ }^{4}$ This was the time of the Ronald Reagan and Margaret Thatcher eras.
} 
of 7 April 1979 had wider political and cultural implications for the entire left-wing movement.

Bettino Craxi, at the head of a group of politicians in their forties - a very young and rampant political class compared with the ruling Christian Democrats-relaunched the Socialist Party under a platform of recovery of national values and identity in a political and economic context. Rhetorical and patriotic speeches, as well as political campaigning, were aimed at boosting Italian exports under the slogan of 'Made in Italy.' Coming after the exhausting years of terrorism, the economic revival was promoted with a large exhibition of Fascist economic and industrial expansion with the title The Italian Economy Between the Wars 1919-1939, held at the Colosseum in November 1984 (Mason 1986). The exhibition was produced by the Post-graduate Institute for Business Studies and Organisation (IPSOA), Italy’s leading school of business management, but its political sponsorship came from the Socialist Party.

Among the many visual images of, and objects from, industrial design and public works achieved during Mussolini's era, the exhibition presented a rich selection of objects from the material culture of the urban middle class. Design objects ranging from ballroom fashions to luxury cars, telephones and other expensive goods were exhibited as if they had been accessible to the entire Italian population (Mason 1986: 12). Images of the department store La Rinascente featured heavily in the exhibition. The connotative link between design production of the Fascist period and that of the 1980s thus suggested a linear model of national modernising development. From the foundation of the Gruppo Finanziario Tessile (GFT) around 1930, which produced the labels Facis and Cori, to the financial backup of GFT to Giorgio Armani, the exhibition metaphorically closed the gap between 1980s consumerism and the process of modernisation that took place in the 1920s and 1930s. Ultimately, the massive spectacle offered by The Italian Economy Between the Wars 1919-1939 presented history in an unproblematic way. The exhibition projected itself as 'an apolitically inclusive, reconciliatory and celebratory act of national documentation' (Mason 1986: 21). ${ }^{5}$ The inclusive nature of the exhibition reflected the political alliance headed by Craxi, a five-

\footnotetext{
${ }^{5}$ Another important exhibition held in Milan in 1982, AnniTrenta: Arte e cultura in Italia, reassessed fascist art patronage as pluralistic and eclectic. The exhibition also dealt with fashion and design. Milan was then run by a Socialist led coalition.
} 
party coalition — the pentapartito —-formed by Christian Democrats, the Socialist Party, the Republican Party, the Social-Democratic Party and the Liberal Party.

\section{Flexible specialisation}

In the wake of the oil crises of the mid-1970s, by the early 1980s Northern Italy had begun to embark on a period of a rapid economic recovery. The renewed prosperity of the regional economy was due to four combined factors. First, commodity prices fell, enabling Italy to import raw material and export its manufactured goods under the relaunched brand of 'Made in Italy.' Second, labour militancy received a historical blow with the October 1980 strike at the Fiat car factory, when forty thousand workers marched against the trade unions. From that date, a hard-line anti-collectivism characterised industrial relations for the following decade. Industrial disintegration was also used as a tool to manage differently the relationship between capital and labour; in fact, the crisis at Fiat began a decade in which sector collective bargaining was abandoned.

The third factor of Italian industrial recovery is directly linked to the second, as it measures the weakening of the unions. In the early 1980s, the system of automatic indexed wages was slowed down, and in 1985 a referendum confirmed its reduction (Sheldon et al. 1997: 90). The effects were measured in the increase in business confidence in investment. Fourth, industrial restructuring embarked on by employers from the middle of the 1970s led to falling rates in industrial employment. Over a million industrial jobs were lost between 1981 and 1991. At the Fiat plant alone, bluecollar workers went from 110,049 in 1980 to 60,180 in 1987 (Sheldon et al. 1997: 90). On the other hand, new skilled jobs were to be found in services or in small and medium firms and factories in Northern and Central Italy, which became the base of a markedly diversified economy. Figures show that in the first five years of the 1980s the indices of employment by economic sector increased by 70 per cent in the tertiary sector, while the employment rate decreased dramatically in agriculture and 10 per cent in industry. By contrast, unemployment was at its height (see tables in Ginsborg 1990: 449-50), a sign that that workers who had lost their jobs in the industry and agriculture sectors were not reabsorbed into the new economy, where jobs were filled by a new generation of professionals - the first generation of Italians to have entered the system of mass education after the 1962 education reform. 
Unemployed workers from large metalworking factories and other industrial sectors found temporary employment in the lavoro nero, or black market economy. In fact, this submerged workforce determined Italian economic recovery during the recession. One estimate from the National Institute of Statistics (ISTAT) identified between 1 and 3.5 million visible irregular workers and two million submerged workers in the black economy (Ginsborg 1999: 58). These workers were employed in both industry and services, from the sweatshops of the informal industrial economy that serviced outsourced work for larger industries, to the small 'textile firms of Apulia, some of which operated in conditions of complete illegality and employed young girls for up to fourteen hours a day’ (Ginsborg 1999: 58).

Along with delocalisation of costly activities to peripheral internal areas, flexible specialisation suited the creative industries; indeed, one of its defining characteristics is the production of a wide range of goods for highly diversified markets. Flexibly specialised industries also continuously modify these goods 'in response to changing tastes and in order to expand their markets' (Storper 1989: 274). A favourable environment was created by the parallel decentralisation of cinema and television in Italy as a response to the economic crisis of the national film industry, and to the rise of local television stations. Thus, with the deregulation of the broadcasting system at the local level in 1976, local television stations numbered 1,594 by 1982, creating economic opportunities for the stations' owners and for local advertising. Advertising agencies mushroomed, and with them came not only an explosion of sector magazines selling space to promote brands, but also market research, opinion polling, audience ratings, consulting, design, graphics and marketing. Along with the publishing sector, these firms were mostly concentrated in Milan.

The creation and expansion of local business communities - a phenomenon historically grounded in Italian regionalism, aggregated around localised specialisation in manufacturing - also sustained the Italian industrial shift from Fordism to a post-Fordist industrial organisation. The textile and clothing industry reflected the pattern in other industries. In the decade 1971-1981, the decline in jobs in large establishments in Turin and Milan was reabsorbed in provincial areas (regional cities in Lombardy, Veneto, Tuscany, Emilia-Romagna, Marche and Apulia), which saw an increase in employment (Dunford 2006: 8). In the 1980s, the localised industrialisation that occurred in the 
countryside in central and north-eastern Italy—-the so-called Third Italy—distinguished itself from the under-developed south and from the larger factories in the more industrialised Milan. The difference consisted in the fact that small manufacturers worked in a cottage industry mode, with labour-intensive stages of production and flexible workforce. This development of small industries was sustained for two reasons: firms were often based on kin relationships, especially in the shoe-producing sector in Tuscany and Marche; and firms employing fewer than fifteen workers were exempt from applying the Statuto dei Lavoratori (Workers' Charter), obtained in 1970 after the 1969 Hot Autumn, a long period of strikes and political unrest.

The Italian leather fashion cluster neatly illustrates the concentration of interconnected companies in a particular field in a particular place. Within this cluster, internationally known brands like Gucci and Ferragamo (Porter 1998: 79) coexisted with many specialist suppliers that serviced the couture or the ready-to-wear brands and that also provided mass-produced leather goods for department stores. A host of linked specialist services such as machinery and tanned leather, which underwent technological modernisation in order to cater for this specialised manufacturing, were part of the same geographical cluster. In the period 1981-1991, a different delocalisation of labour occurred, as losses in unskilled jobs in the northern regions corresponded to increases in the South. As we have seen in the example cited by Ginsborg (2001), Southern Italy provided cheap labour and played an important role in the evolution of the 'Made in Italy’ system.

Milan was, and still is, the centre of the 'magic circle' (Dunford 2006: 10) serviced by industrial districts that comprise textile and other manufacturing activities gravitating in an orbit around the city. Often vertically organised and geographically diversified, wool manufacturing was (and remains) centred in Biella (Piedmont) and Vicenza (Veneto), while Como is the traditional manufacturer for silk, and Palazzolo sull’Oglio (Lombardy) for cotton, buttons and button-making machines, and so on (2006: 10). Thus, while small to medium firms were organised internally according to flexible specialisation, and were often based on the family unit, the unique model of the Italian fashion system was organised in a vertical integration model of production, from fibre to the finished product. As Steele puts it, this was an example of production and 
distribution that other countries have tried to replicate with little success (Steele 2003: 2).

\section{Anti-fashion, material culture and consumption}

The 1984 historical exhibition of the Fascist economy effectively created a link between the Fascist economy, technology and design, and the technological innovation and economic growth of the 1980s. With the disaffection from politics, agency and identity were rearticulated into the stylised world of aesthetics and consumption. Postmodern theory has been mobilised to account for the broad cultural and social change that occurred from the end of the 1970s. But, more importantly, mass market advertising has seized upon the cultural logic of postmodernism to produce 'meanings mediated through claims to truth represented in images that circulate in an electronic, informational hyperspace, which disassociates itself from history, context and struggle' (Girouz 1994-95: 6). By the end of the 1970s, fashion, design, architecture and art had definitely broken with modernism, drawing freely from this decontextualised use of history. In turn, the 1980s were the years dedicated to the material world, as exemplified by an obsession with fitness ${ }^{6}$ and career, the launch of pop stars, and the rapid rise of fashion stylists and brands. Because mass marketing provides a pedagogic platform that uses badges of identity and group membership to create desire, pleasure and socialisation through consumption, material possession and shopping became the means to satisfy various individual needs in lieu of collective participation in civic and political life.

As the Italian urban ceti medi (middle class) grew from 38.5 per cent in 1970 to 46.4 per cent in 1983, and the inflation rate fell from 21.1 per cent in 1980 to 4.6 per cent in 1987 (Ginsborg 1990: 406-7, 410), Italian families had more disposable income to spend on luxury goods. Consumerism was also assisted by tax incentives that favoured an expanded oligarchy of sophisticated consumers; on the basis of a survey conducted in 1987, this oligarchy corresponded to 38.8 per cent of the population (Santarelli 1996: 298). Thus ready-to-wear was the most appropriate style to accompany urban lifestyles and cosmopolitanism. William Scobie, the Observer's reporter in Italy, wrote about Italy’s second miracle:

\footnotetext{
${ }^{6}$ Lara Saint Paul imported aerobic dancing in the 1980s. Her successful studio in Via Procaccini, in the Sempione suburb, was attended by hundreds of professional women.
} 
Italy finally has become, in 1987, one of Europe's greatest success stories. Suddenly, this is a land of upward mobility, of vital computerized industry, bustling young business managers and slick middleprofit. Class war is passé. Export or die. (Scobie, cited in Ginsborg 1990: 409)

This link between commerce and politics was aptly represented by Benetton's advertising campaigns, which aimed at incorporating public statements on a number of social issues into its images. Fiorucci, on the other hand, targeted the youth market, opening stores it hoped would replicate the Swinging London revolution of the 1960s. Its first concept store in Galleria Passerella in Milan, whose logo was publicised by the little angels re-elaborated by Italo Lupi in the 1970s, became the icon of Italian streetstyle. Much has been written about dressing codes of the 1960s and 1970s tribes and about 1970s anti-fashion (Steele 1997, 2000), but scholarship has tended to focus on Anglo-American societies. Milan can also be taken as an example of the fashion developments and tensions of the 1970s in Italy. The Italian case is unique because of the way in which some of the most anti-establishment groups of the left, from an initial refusal of fashion-including its most avant-garde expressions-as symbolic of consumerism, ended up desiring brand clothing following a confused concept of what individual freedom of expression meant. In the name of 'proletarian expropriation,' during the frequent violent demonstrations in Milan in the 1970s, groups of the extreme left regularly shattered shop windows and stormed inside boutiques, including the Fiorucci store, to appropriate the products of capitalist exploitation,n especially Fiorucci jeans. In this way, and quite ironically, Fiorucci offered Italian youth the possibility of re-establishing a link between fashion and oppositional youth movements, when the latter, using less conventional methods, combined items signifying antifashion and street style.

The rearticulation of identity through appearance went hand in hand with another parallel process in the 1970s. This was the diffusion of horizontal consumerism due to the growth of an urban bourgeoisie, with the consequent creation of a multi-level middle class. But most importantly, it must be noted that the Italian approach to anti-fashion was well defined from the beginning. Italian political tribes distinguished themselves above all through their clothing: large dark blue or military green parkas with jeans and military boots for the left; short aviator leather jackets, jeans, pointy boots and RayBans for the so-called Sanbabilini, the extreme right-wing groups named after Piazza San Babila in Milan, their meeting place, only a few metres away from the Fiorucci 
store. During the most conflict-ridden periods of political activism, people wearing parkas would stay clear of San Babila, as they would be readily identified as left-wing activists and physically attacked.

With the explosion of the feminist movement after 1972, women who were initially political activists in groups of the left declared war against mini-skirts and any fashionable item that had an explicit sexual reference, including makeup. Italian feminist groups thus adopted the midi-skirt, often in flower prints, with oversized, handmade knits, shawls and clogs. Feminists were the regular customers of vintage and second-hand clothing shops that by the middle of the 1970s were flourishing in Milan, especially around Via Solferino, Corso Garibaldi and Via Fiori Chiari and Fiori Oscuri, in the Brera-Solferino area. Small cottage manufacturing of hippy knick-knacks and jewellery, and shops that imported jewellery and clothing from India, flourished in the same area. Because of its artistic, bohemian demographic, Brera became the object of real estate speculation, which transformed the suburb through expensive renovations of its buildings.

The immense social, political and cultural changes brought about by the 1960s and 1970s thus irreversibly modified relationships between genders, political power and social base, and classes. The increasing politicisation of Italian youth led them to refuse 'fashion,' deemed to be representing the essence of capitalism and consumerism, and thus to despise new youth brands such as Fiorucci. Eventually, however, the new consumer of the 1980s was born from the three-storey Fiorucci shop.

\section{The rise of 'Made in Italy'}

To the international travellers who land at Malpensa airport and travel to the city via train and stopping at Stazione Cadorna, the Ago e Filo (Needle and Thread) sculpture in Piazza Cadorna by American pop artist Claes Oldenburg, reminds them immediately that Milan is the Italian capital of fashion. An 18 metre-tall needle in steel, with yellow, green and red threads in fibreglass around it - the colours of the three subway routeswhich resurface metres away in the square and ends with a knot, is a playful sculpture commissioned in 2000 by Gae Aulenti as part of the restructure of the square. In reality, the monument celebrates thirty years of the laboriosità (industriousness) of Milanese people, who with their working ethos have contributed to Milan's construction as one of 
the three international capitals of style. But the Ago e Filo might mean something completely different to the thousands of commuter workers who arrive daily at the Stazione Cadorna from the outskirts and the provincia, and even more so to the many migrants from East Europe and Africa who gravitate to the area around the station. The 'Made in Italy' concept was a clever revival from the 1950s, when it first appeared in Florence and Rome with haute couture and design. However, in the 1950s Italy continued to suffer from the weight of France's supremacy in fashion. In a situation similar to Italy's dependence on France in the early days of cinema, when professionals and technology were imported from French companies such as Paté and Gaumont, premières (first hands) and patterns were imported from French couture by Italian dressmakers. Design production was an elitist phenomenon (Capellieri 2007: 33), although the launch of the Italian fashion show in Florence in 1951, when Giovanni Battista Giorgini staged the first show of Italian fashion for foreign buyers (Dizionario della Moda, n.d.), was fundamental to the projection abroad of a fashion that was comfortable and affordable. This event introduced the system of sizes and forced the textile industry to rearrange itself in line with a Fordist mode of production (Barile 2006: 138). Indeed, the adaptation of French haute couture for the more modest Italian market in the 1950s might have forced upon Italian fashion designers the concept of developing more comfortable and unstructured clothes for ready-to-wear.

Much has been written about US economic aid in Italian postwar reconstruction (White 2000); indeed the acquisition of up-to-date technology helped all industrial sectors, including the textile sector, to recover from the destruction of the war. However, it is often forgotten that the post-war recovery of the Italian clothing industry was also driven by the fact that Italy had been the largest exporter of silk and wool textiles to Paris between the wars. The renewed success of textile export was thus based on an established tradition. Of course, the superior quality of Italian textiles was fundamental in helping the sector to expand.

In the 1960s, there were already designers who worked in Milan: Mila Schön, Biki and Walter Albini- the last of these working with five different companies. But the turning point in the evolution of the 'Made in Italy' as we know it today was the move of some designers and companies from Florence to Milan to show their collections in 1972. As Valerie Steele puts it, unlike Florence and Rome, Milan had never distinguished itself as 
a centre of art and culture (Steele 2003: 59). The city was, however, the centre of industrial design, and it was an industrial city. Design and fashion have more than a practical connection, as they both share the Latin root from habere, which means to have, to possess. Thus abitare and abito (to inhabit and garment) represent a point of intersection between design and fashion that emerged in the 1970s, through magazine specialising in architecture and design, such as Domus and In, which started to promote fashion design (Colaiacomo 2006: 9). This connection is also made evident by Gianfranco Ferrè, who initially trained as an architect. In that period, there were no fashion courses at tertiary level and the only way to graduate in design was to follow a study path at the Politecnico in Milan. Thus fashion and design developed in synergy, thanks also to design studios and brands such as Alchimia and Memphis, which from the early 1980s were pivotal in establishing the new ethos of content=image=market. At this stage, Milan became the capital of ready-to-wear and design, a magnet for postmodern creativity.

Giorgio Armani aptly defined Milan’s understated modernity when he commented on how he covered the frescos on the walls in his headquarters in via Borgonuovo:

In Florence, you would look up there ... in Milan you look this way ... Milan is not apparently elegant, but you must seek it out. Its elegance is more subtle than other cities. You can find it in courtyards, in certain details, in the interiors of certain houses. True elegance is that which is most subtle and hidden. (Armani, quoted in Cocks 1982: 51)

Armani's view about Milan's sophisticated, low-key elegance reflected the way in which he then revolutionised the ready-to-wear concept by giving form to a style that emerges without excessive design. But most importantly, Armani was inspired by the understated elegance of middle- and upper-class, middle-aged Milanese women. For decades they had been wearing tailored suits, simple tweed pencil skirts and twin-sets in soft colours, or they bought their understated, easy-to-wear clothes from Max Mara, which had been operating since 1951. Milanese women's quiet and elegant fashion gave rise to the popular saying: 'In Milan, women spend a lot of money to appear less.'

To reflect Milan’s industrial background, Armani restructured and tailored clothes with layers of fabrics, colours and textures it was once believed possible to make only by hand, but which were in fact made industrially. Naturally, Armani was pivotal in the expansion of the 'Made in Italy’ abroad. 'Surely, we had Walter Albini, Pucci and 
Valentino, but the real explosion of the Made in Italy starts with Armani,' said Franca Sozzani, editor-in-chief of Vogue Italia, in an April 2007 interview with the author. In 1976, Fred Pressman, president of Barney's in New York, introduced Armani in the USA. From US $\$ 90,000$ of combined sales of the men’s and women's lines in 1976, in 1982 Armani’s revenues from the American market were estimated at US\$135 millions, a 60 per cent increase on the previous year (Cocks 1982: 51).

Even before the expansion of the 'Made in Italy' in the Italian domestic market, the USA was importing 70 per cent of its overseas clothes purchases from Armani and other designers in Milan, much to the grief of Paris's couturiers. By 1982, garments by the designers Mariuccia Mandelli (better known as Krizia), Ottavio and Rosita Missoni, Valentino and Fendi were already in museums in the United States and around the world (Di Forti 1982: 85). Despite the domestic scepticism about what some people labelled 'luxury rags,' in 1981 exports of ready-to-wear put the Italian balance of payments into a surplus of 4,417 billion lira (1982: 85). Textile exports were also at their peak, reaching 8,647 billion lira in 1982 (1982: 97).

In an interview in 1982, Versace said: 'We work half way between art, craftsmanship, and industry ... I feel a lot the influence of the artisan tradition, which in Italy has deep roots and is integrated with family life.' (quoted in Di Forti 1982: 87) The Italian look was multifaceted, but the success of 'Made in Italy' in the 1980s was essentially based on a vague stereotype of Italian creativity in innovation, which found its underpinning in intangible factors conjured up by the aesthetic and cultural inheritance of the Italian Renaissance. The designers themselves also perpetrated these stereotypes, and international photographers also frequently stress this point by alluding in their styling to Renaissance masterpieces (Cheles 2002). Thanks to this inheritance, the 'Made in Italy' brand was able to combine 'high culture' with craftmanship in its claims of quality and excellence in materials and execution. Within an economy of flexible specialisation, and thanks to traditions of craftmanship linked to territory, some Italian regions were able to innovate and convert their traditional production in line with a logic of specialisation on local scale. As in the nineteenth century, in which the textile sector heavily contributed to the expansion of the Italian industry, fashion became the most important international ambassador for Italy in this period. 


\section{Vogue Italia}

This article has argued that the evolution of 'Made in Italy' was a multi-dimensional phenomenon, one also sustained by the profound changes that occurred in the Italian social fabric, economy and culture. The depreciation of the Italian lira was also fundamental in sustaining the rapid internationalisation of Italian prêt-à-porter. But more importantly, in the 1980s the many fashion magazines, which mushroomed in Milan, also played a pivotal role in the internationalisation of the 'Made in Italy' brand. Several new ventures, such as Donna, Moda and Uomo Moda, reflected the euphoria of the moment, while others were Italian versions of international magazines such as Elle and Marie-Claire, both of which launched their Italian editions in 1987.

However, the most important fashion magazine that contributed actively to the promotion of the 'Made in Italy' logo through its influential promotion of designers was Vogue Italia. In fact, the Ago e Filo sculpture is not casually placed in Piazza Cadorna, as only one block away, on the right-hand side of the square, is the building housing Vogue Italia's headquarters. The magazine was launched in 1964 as Novità/Vogue Italia, becoming Vogue in 1966. Between 1966 and 1987, Vogue Italia's editor-in-chief was Franco Sartori, who also took on the role of chief executive officer for the Italian branch of American Condè Nast. From 1987, Franca Sozzani, who was the editor-in-chief of Lei (the Italian version of Glamour) and then Per Lui (a monthly magazine dedicated to young men that ceased publication in 1991), became editor-in-chief of Vogue Italia. Since the 1970s Sozzani has become the most influential media woman in Milan fashion, and in her position at Lei, she was fundamental in the promotion of ready-towear brands aimed at a young market. Thus, in order to make the magazines that were under her directorships successful, Franca Sozzani had to promote the 'Made in Italy' and turn it into an international success story. Like every other fashion magazine, Vogue Italia promoted brands and designers who would invest heavily in advertising by giving them exposure in its editorial pages.

Since her directorship, Vogue Italia has made a substantial change, becoming, as one commentator has claimed, the 'best and most beautiful fashion magazine in the world' (Steele 2003: 117). Fundamental in this evolution was the magazine's philosophy of rearranging various key garments from different designers and presenting them in a mix-and-match. That approach anticipated the change of the fashion system from the 
total look of the 1980s to the success of 1990s grunge, by which people combined their favourite clothes freely (Franca Sozzani, quoted in Cappellieri 2007: 169). Sozzani explained in an April 2007 interview with me that: 'We do not present what women should wear-for example, coats, or another issue could be about skirts. We combine different pieces and create trends and a completely new aesthetic.' In the 1990s, the aesthetic strategy was to utilise the best fashion photographers in the world, while starting to use English titles and English language in the texts contributed to what Franca Sozzani calls 'sdoganare Vogue Italia'—literally 'clear through the customs,' or internationalisation of the magazine.

'Made in Italy' proposed a cultural and industrial model to the rest of the world, but more importantly it worked as a catalyst for the forging of a new identity in Italy, based on consumerism and a new culture of appearance. This transformation was a response to the gloomy years of terrorism, but also and especially the result of horizontal levelling of consumption. The wider access to the market of luxury goods destabilised the traditional social pyramid, generating a new kind of consumer whose values were grounded in hedonism and personal happiness. The collapse of Wall Street in 1987, the fall of the Berlin Wall in 1989, the first Gulf War in 1991 and the Tangentopoli inquiry in 1992 subverted existing values and signalled that the era of opulence was finished. But that is another story. 


\section{Reference List}

Barile, N. 2006, 'Made in Italy: da Country of Origin a Metabrand,' in Fatto in Italia: La cultura del Made in Italy (1960-1980), (ed.) P. Colaiacomo, Meltemi, Roma, 133-57.

Barzini, A. (dir.) 1990, Italia-Germania 4 a 3, Radiotelevisione Italia.

Cappellieri, A. 2007, Moda e design: il progetto dell'eccellenza, Franco Angeli, Milano.

Cheles, L. 2002, “Influssi rinascimentali sulla fotografia di moda contemporanea”, in Il vestito e la sua immagine, (ed.) J. Guerin Dalle Mese, Provincia di Belluno Editore, Belluno, 313-23.

Cocks, J. 1982, 'Suiting Up for Easy Street,' Time, 5 April, 46-55.

Colaiacomo, P. 2006, 'Introduzione,' in Fatto in Italia: La cultura del made in Italy (1960-2000), (ed.) P. Colaiacomo, Meltemi, Roma, 7-25.

Di Forti, M. 1982, 'Che stile!,' L’Espresso, 2 May, 82-94.

Diamanti, I. \& Lazar, M. 1997, Stanchi di miracoli: Il sistema politico italiano in cerca di normalità, Guerini e Associati, Milano.

Dizionario della Moda. N.d. Online. Available: http://dellamoda.it/fashion_dictionary/s/sala_bianca.php (Accessed 10 September 2008).

Dunford, M. 2006, 'Industrial Districts, Magic Circles and the Restructuring of the Italian Textiles and Clothing Chain,' School of Social Sciences and Cultural Studies, University of Sussex, Falmer, Brighton.

Ginsborg, P. 1990, A History of Contemporary Italy: Society and Politics 1943-1988, Penguin, London. Ginsborg, P. 2001, Italy and its Discontents, Allen Lane/Penguin, London/New York.

Giroux, H. 1994-95, 'Consuming Social Change: The "United Colors of Benetton,”' Cultural Critique, Winter: 5-32.

Mason, T. 1986, ‘The Great Economic History Show,’ History Workshop Journal, Spring, no. 21: 3-35.

Porter, M. E. 1998, 'Clusters and the New Economics of Competition,' Harvard Business Review, November-December: 77-90.

Santarelli, E. 1996, Storia critica della repubblica L'Italia dal 1945 al 1994, Feltrinelli, Milan.

Sassoon, D. 1995, 'Tangentopoli or the Democratization of Corruption: Considerations on the End of Italy’s First Republic,' Journal of Modern Italian Studies, no. 1: 124-43.

Segre Reinach, S. 2006, 'Milan: The City of Prêt-à-Porter in a World of Fast Fashion,' in Fashion’s World Cities, (eds) C. Breward \& D. Gilbert, Berg, Oxford, 123-34.

Sheldon, P., Thornthwaite, L. \& Ferrero-Regis, T. 1997, 'The Federmeccanica: Its Changing Commitment to Collectivism and the Remaking of Industrial Relations in Italy, 1980-1995,' in Collectivism and Individualism: Trends and Prospects, Proceedings of the Fifth IIRA European Regional Industrial Relations Congress: 'The Employment Relationship on the Eve of the Twentyfirst Century,’ Dublin, 26-29 August, (eds) D. D’Art \& T. Turner, Oak Tree Press, Dublin, 77-97.

Steele, V. 1997, 'Anti-Fashion: The 1970s,' Fashion Theory, vol. 1, no. 3, 279-96.

Steele, V. 2000, 'Fashion: Yesterday, Today \& Tomorrow,' in The Fashion Business: Theory, Practice, Image, (eds) N. White and I. Griffiths, Berg, Oxford, 7-20.

Steele, V. 2003, Fashion, Italian Style, Yale University Press, New Haven.

Storper, M. 1989, 'The Transition to Flexible Specialisation in the US Film Industry: External Economies, the Division of Labour, and the Crossing of Industrial Divides,' Cambridge Journal of Economics, no. 13: 273-305.

White, N. 2000, Reconstructing Italian Fashion, Berg, Oxford.

Wilson, E. 1985, Adorned in Dreams: Fashion and Modernity, Virago, London. 